\title{
A Novel Subspecies of Mouse DNA Polymerase $a$ : Variations of the Activity during Postnatal Tissue Development and its Subcellular Location
}

\author{
Tomoko Kozu, Tatsuo Yagura and Takeshi Seno \\ Department of Immunology and Virology, Saitama Cancer Center Research \\ Institute, Ina-machi, Kitaadachi-gun, Saitama 362, Japan
}

\begin{abstract}
In rapidly proliferating Ehrlich ascites tumor cells, DNA polymerase activity has been found which utilizes poly $(\mathrm{dC})$ as a template without added primer. The DNA polymerase responsible for this activity and its stimulating factor were partially purified as reported previously (26). To obtain information on the role of this novel activity in DNA replication, subcellular location and developmental change were studied. The DNA polymerase activity in a crude extract prepared from Ehrlich ascites cells that utilizes single-stranded DNA was characterized by mixing it with purified DNA polymerase and by trypsin digestion. We thus obtained evidence that the activity in crude extract was the same as that of the purified enzyme. The activity in a subcellular fraction, prepared by the procedure using cytochalasin B induced enucleation, was determined. More than $98 \%$ of the activity was found in the karyoplast. We then measured the levels of activity in the spleen and in cardiac muscle, both of which show the characteristic pattern of cellular proliferation during postnatal development. In both tissues, the levels of activity were correlated positively with the rate of DNA synthesis. These results suggest that this novel DNA polymerase activity participates in DNA replication.
\end{abstract}

DNA replication in eukaryotic cells probably is initiated with primer RNA synthesis followed by DNA polymerization at a site of transient single-stranded DNA produced by the binding of specific proteins. But, whereas the majority of studies support the contention that DNA polymerase $\alpha$ is the true replication enzyme in mammalian cells $(1,5,9,13,27)$, no successful in vitro reconstitution of de novo DNA synthesis with DNA polymerase $\alpha$ and the known mammalian RNA polymerase has reported. Several studies, incruding ours, have shown anomalous DNA polymerase activity in rapidly proliferating cells which could utilize poly $(\mathrm{dC})$ as a template without added primer $(10,14,17,20,26)$. Two of these studies showed co-purification of DNA polymerase activity with RNA polymerase that utilizes poly $(\mathrm{dC})(14,17)$. Morris and Racine, in their study of the sea urchin embryo, did not find this RNA polymerase active in priming strict deoxyhomopolymer synthesis by co-purified DNA polymerase (17).

The DNA polymerase-utilizing poly $(\mathrm{dC})$ of Ehrlich ascites tumor cell earlier reported by us (26) may differ from those others reported $(10,14,17,20)$ because this polymerase activity with poly $(\mathrm{dC})$ requires a specific protein factor (stimulating factor). This DNA polymerase has properties characteristic of DNA polymerase $a$ which 
suggest that it is one of a subspecies of DNA polymerase $a$. Thus we designated it DNA polymerase $\alpha_{1}$.

During further characterization of this activity, we found novel properties of this DNA polymerase activity with single-stranded DNA as the template; this activity was associated with RNA polymerase activity that was clearly distinguished from the activity of known mouse RNA polymerases (28). This new RNA polymerase activity was active in priming DNA synthesis with single-stranded DNA; thus, it differed from the activity reported for sea urchin RNA polymerase (17). These facts suggest that this RNA polymerase associated DNA polymerase activity may have a role in initiating DNA synthesis in vivo.

To verify the involvement of this enzyme in DNA replication, the localization of its activity in the nucleus and a positive correlation between activity levels and the rate of cellular DNA synthesis are of primary importance. We have thus examined the subcellular location and correlation of the levels of DNA polymerase $\alpha_{1}$ activity with the rate of cellular proliferation during postnatal development of the spleen and cardiac muscle.

\section{MATERIALS AND METHODS}

Animals and cells. ICR mice (Clea, Japan) of both sexes were used. Ehrlich ascites tumor cells in the mid-log phase of growth were harvested from the abdominal cavities of the mice. The tumor cells were washed once with $3 \mathrm{mM} \mathrm{CaCl}_{2}$ to remove erythrocytes and leucocytes, then washed twice with phosphate-buffered saline.

Reagents. All radioactive materials were obtained from Amersham, Ltd. England. Unlabeled deoxyribonucleoside 5'-triphosphates, GTP, poly(dT), poly(dA), poly(dG), and oligo(dG) were from P-L Biochemicals; poly $(\mathrm{dC})$ from Miles Lab.; oligo(rA) from Collaborative Research; Calf thymus DNA, bovine serum albumin, trypsin (Type XI), soybean trypsin inhibitor (Type 1-S), cytochalasin B, phenylmethylsulfonyl fluoride from Sigma and Ficoll 400 from Pharmacia Fine Chemicals. Activated calf thymus DNA was prepared as described earlier (11).

Measurement of $\left[{ }^{3} \mathrm{H}\right]$ thymidine incorporated into the DNA of the spleen and cardiac muscle. Mice from each postnatal developmental stage and from the 18th day of gestation were injected subcutaneously with $\left[{ }^{3} \mathrm{H}\right]$ thymidine $(2 \mu \mathrm{Ci} / \mathrm{g}$ of body weight). After $1 \mathrm{~h}$, the mice were killed and their heart venticles and spleens removed. These tissues were homogenized in ice-cold $0.15 \mathrm{M} \mathrm{NaCl}$ to which an equal volume of ice-cold $10 \%$ trichloro acetic acid was added. The acid-insoluble materials were collected by centrifugation and washed twice with ice-cold $5 \%$ trichloroacetic acid, then twice more with ethanol/ether (3/1). The washed materials were suspended in $5 \%$ trichloroacetic acid and heated for $30 \mathrm{~min}$ at $70^{\circ} \mathrm{C}$. The supernatant fractions obtained by centrifugation were measured for DNA content and radioactivity.

Subcellular fractionation. The enucleation procedure with cytochalasin B (25) was used for subcellular fractionation. Ehrlich ascites cells were washed with phosphate-buffered saline and suspended in $12.5 \%$ Ficoll 400 in Eagle's minimum essential medium containing $1.89 \mathrm{mM}$ EDTA, $7.5 \mathrm{mM}$ Hepes (pH 7.4) and $10 \mu \mathrm{g} / \mathrm{ml}$ cytochalasin B $\left(1 \times 10^{7}\right.$ cells $\left./ \mathrm{ml}\right)$. Three milliliter portions of the cell suspensions were layered on Ficoll discontinuous gradients, which had previously been kept at $37^{\circ} \mathrm{C}$ for $6 \mathrm{~h}$. The layered gradients were centrifuged in a Hitachi RPS 40T rotor for $60 \mathrm{~min}$ at $77,600 \times \mathrm{g}, 37^{\circ} \mathrm{C}$. After centrifugation, the band of cytoplasts was collected with a sylinge and diluted with $50 \mathrm{mM}$ Tris- $\mathrm{HCl}(\mathrm{pH} 7.6), 0.5 \mathrm{M}$ 
$\mathrm{KCl}, 2 \mathrm{mM}$ dithiothreitol and $0.5 \mathrm{mM}$ phenylmethylsulfonyl fluoride. The karyoplasts were pelleted at the bottom of tube and suspended in the above buffer. Crude extracts from the cytoplasts and karyoplasts were prepared by the method used for the cell extracts as described below.

Preparation of cell and tissue extracts. Crude extracts of Ehrlich ascites cells and tissues essentially were prepared according to the method described earlier (26), except that the spleens and cardiac muscles were homogenized with a glass homogenizer fitted with a Teflon pestle before sonication in the buffer containing $0.5 \mathrm{M} \mathrm{KCl}$. The sonicates were centrifuged at $100,000 \times \mathrm{g}$ for $2 \mathrm{~h}$ at $4^{\circ} \mathrm{C}$ after which the supernatants were dialyzed against the buffer containing $50 \mathrm{mM}$ Tris- $\mathrm{HCl}(\mathrm{pH} 7.6), 5 \mathrm{mM} \mathrm{KCl}, 2 \mathrm{mM}$ dithiothreitol, $20 \%$ glycerin and $0.2 \mathrm{mM}$ phenylmethylsulfonyl fluoride. The supernatant fractions obtained by high speed centrifugation of this solution were used as the crude extracts.

DNA polymerases assay. The reaction mixture for the DNA polymerase $\alpha_{1}$ in the crude extract contained $(50 \mu \mathrm{l}): 50 \mathrm{mM}$ Tris- $\mathrm{HCl}(\mathrm{pH} 7.6), 40 \mathrm{mM} \mathrm{KCl}, 1 \mathrm{mM}$ dithiothreitol, $2 \mathrm{mM}$ $\mathrm{MgCl}_{2}, 0.2 \mathrm{mg} / \mathrm{ml}$ bovine serum albumin, $25 \mu \mathrm{M}\left[{ }^{3} \mathrm{H}\right] \mathrm{dGTP}(0.72 \mathrm{Ci} / \mathrm{mmol}), 20 \mu \mathrm{g} / \mathrm{ml}$ poly(dC) and $1-3 \mu 1$ of the crude extract. In the purification of DNA polymerase $\alpha_{1}$, activity was assayed with the reaction mixture described above, except that $0.5 \mathrm{mM}$ GTP and the stimulating factor were added. The stimulating factor used was purified as described previously (26) with some modifications (28). Incubation was at $37^{\circ} \mathrm{C}$ for $30 \mathrm{~min}$. After incubation, $40 \mu \mathrm{l}$ of the reaction mixture was spotted on a glass filter $(\mathrm{GF} / \mathrm{C})$ and the radioactivity of the material was measured as described previously (11).

DNA polymerases $\gamma$ and $\alpha$ were assayed as described previously (12).

Purification of DNA polymerase $\alpha_{1}$. The purification of DNA polymerase $\alpha_{1}$ is described in detail elsewhere (28). The crude extract of Ehrlich ascites cells, prepared as described above, first was fractionated by backwashes of ammonium sulfate precipitate as described by Mechali et al. (16). The active fractions of the backwashes were applied to a DEAEcellulose column and the enzyme was eluted with a linear gradient of $\mathrm{KCl}$. In this experiment, poly $(\mathrm{dC})$-dependent DNA polymerase activity was assayed in the presence of $0.5 \mathrm{mM}$ GTP. Results are shown in Fig. 1. DNA polymerase $\alpha$ activity assayed with activated DNA was eluted at $0.2 \mathrm{M} \mathrm{KCl}$ with a small shoulder at $0.15 \mathrm{M} \mathrm{KCl}$, whereas DNA polymerase $\gamma$ assayed with poly $(\mathrm{rA}) \cdot$ oligo(dT) was eluted at $0.11 \mathrm{M} \mathrm{KCl}$. The poly $(\mathrm{dC})$-utilizing activity was eluted in a single peak at $0.15 \mathrm{M} \mathrm{KCl}$, which was coincident with the minor activity peak of DNA polymerase $a$. The stimulating factor was eluted at $0.08 \mathrm{M} \mathrm{KCl}$. Since the DNA polymerase activity assayed with activated DNA was copurified with the poly(dC)-utilizing activity, this species of DNA polymerase activity was designated polymerase- $\alpha_{1}$. The species (major one) eluted later was designated polymerase- $\alpha_{2}$. Both enzymes were further purified by successive chromatography on phosphocellulose, hydroxyapatite and DNA-cellulose columns. These purified enzymes were stored in liquid nitrogen and remained stable for several months.

Protein and DNA determination. The method of Lowry et al. (15) was used for the protein determination with bovine serum albumin as the standard. DNA was measured by the Burton modification of the diphenylamine reaction (3) with calf thymus DNA as the standard.

\section{RESULTS AND DISCUSSION}

Template and substrate specificities of DNA polymerase activity in the crude extract utilizing single-stranded $D N A$. We used crude extract as a source of enzymes to study subcellular location and developmental change, because the activity utilizing 
poly $(\mathrm{dC})$ and poly( $\mathrm{dT})$ consisted of DNA polymerase associated with RNA polymerase activity and its stimulating factor $(26,28)$ and separation of DNA polymerase from its stimulating factor would cause loss of activity. But, the crude extract contains several factors which might influence activity; therefore it was necessary to identify the activity in the crude extract with that of purified DNA polymerase $\alpha_{1}$. Thus, the activity in the crude extract was compared with DNA polymerase $\alpha_{1}$ which had been purified as described in MATERIALS AND METHODS. The purified polymerase$\alpha_{2}$ has no single-stranded DNA-dependent DNA polymerase activity.

Table 1 shows that the crude extract prepared from Ehrlich ascites cells contained single-stranded DNA-dependent DNA polymerase activity for which the template specificity was comparable to that of purified enzyme (26). The activity in the crude extract was active with single-stranded DNAs other than poly(dA) and poly(dG). An addition of purified polymerase- $\alpha_{1}$ to the reaction mixture of crude extract containing poly $(\mathrm{dC})$ or poly $(\mathrm{dT})$ markedly stimulated dGTP or dATP incorporation into acid insoluble material, whereas the addition of purified polymerase- $\alpha_{2}$ did not. This is evidence that the activity that uses poly $(\mathrm{dC})$ and poly $(\mathrm{dT})$ in the crude extract is identical with that of polymerase- $\alpha_{1}$.

Polymerase- $a_{1}$ or $-\alpha_{2}$ stimulated the incorporation of dTTP on denatured DNA in an amount greater than the activities of the crude extract and the added polymerase (Table 1 lane 7). Some of this stimulation may be ascribed to protein factors present in the crude extract which are known to stimulate DNA polymerase $\alpha$ assayed with denatured DNA $(18,19,20)$. But the DNA synthesis produced by polymerase- $\alpha_{2}$ with denatured DNA in the crude extract seems to differ greatly from that produced

TABLE 1. TeMPIATE SPECIFICITY OF SINGLE STRANDED DNA-DEPENDENT DNA POLYMERIZING ACTIVITY IN CRUDE TUMOR CELL EXTRACT AND THE EFFECT OF ADDED DNA POLYMERASE $a_{1}$ AND $a_{2}$

\begin{tabular}{|c|c|c|c|c|c|c|c|}
\hline \multirow[b]{2}{*}{ Template $^{\mathrm{a}}$} & \multicolumn{2}{|r|}{ Substrate $^{\mathrm{b}}$} & \multicolumn{5}{|c|}{$\left[{ }^{3} \mathrm{H}\right] \mathrm{dNMP}$ incorporated $(\mathrm{pmol})$} \\
\hline & ${ }^{3} \mathrm{H}$-labeled & Unlabeled & $\begin{array}{l}\text { crude } \\
\text { extract }\end{array}$ & $\alpha_{1}{ }^{\mathrm{c}}$ & $\begin{array}{l}\text { crude } \\
\text { extract } \\
+a_{1}\end{array}$ & $\alpha_{2}{ }^{\mathrm{c}}$ & $\begin{array}{l}\text { Crude } \\
\text { extract } \\
+\alpha_{2}\end{array}$ \\
\hline None & dGTP & & 0.6 & 0.3 & 0.8 & 0.4 & 1.2 \\
\hline None & dTTP & dATP, dCTP, dGTP & 1.1 & 0.1 & 1.7 & 0.1 & 1.2 \\
\hline$(\mathrm{dC})_{\mathrm{n}}$ & dGTP & & 10.1 & 0.6 & 35.4 & 0.4 & 9. 0 \\
\hline$(\mathrm{dT})_{\mathrm{n}}$ & dATP & & 25.4 & 2.6 & 112 & 0.3 & 33.1 \\
\hline$(\mathrm{dA})_{\mathrm{n}}$ & dTTP & & 0.2 & 0.3 & 0.2 & 0.1 & 0.2 \\
\hline$(\mathrm{dG})_{\mathrm{n}}$ & dCTP & & 0.5 & 0.1 & 0.6 & 0.1 & 0.4 \\
\hline Denatured DNA & dTTP & dATP, dCTP, dGTP & 71.3 & 20.8 & 403 & 3.9 & 191 \\
\hline
\end{tabular}

Reaction conditions are described in MATERIALS AND METHODS, but the template and substrate were altered as shown. Incubation took place at $37^{\circ} \mathrm{C}$ for $30 \mathrm{~min}$. The DNA polymerases $a_{1}$ and $a_{2}$ used were 0.37 units and 0.33 units when assayed with activated DNA. The DNA polymerase activity in the crude extract with activated DNA was 0.23 units. One unit corresponds to $1 \mathrm{nmol}$ of dNMP incorporated within $60 \mathrm{~min}$ at $37^{\circ} \mathrm{C}$.

a The reaction mixture contained $20 \mu \mathrm{g} / \mathrm{ml}$ of synthetic homopolymer or $50 \mu \mathrm{g} / \mathrm{ml}$ of heat denatured calf thymus DNA.

b The concentration of each dNTP was $25 \mu \mathrm{M}$. The specific activity of each labeled substrate was $0.77 \mathrm{Ci} / \mathrm{mmol}$ for dCTP; $0.77 \mathrm{Ci} / \mathrm{mmol}$ for dATP; $0.79 \mathrm{Ci} / \mathrm{mmol}$ for $\mathrm{dTTP}$ and $0.72 \mathrm{Ci} / \mathrm{mmol}$ for dGTP.

c $a_{1}, \alpha_{2}$; DNA polymerase $\alpha_{1}$ and $\alpha_{2}$ purified as described in MATERIALS AND METHODS were used. 
TABLE 2. SUBSTRATE SPECIFICITY OF POLY(dC)-DEPENDENT DNA POLYMERIZING ACTIVITY IN CRUDE TUMOR CELL EXTRACT AND THE EFFECT OF EXOGENOUSLY ADDED DNA POLYMERASE $\alpha_{1}$

\begin{tabular}{|c|c|c|c|}
\hline \multicolumn{2}{|c|}{ Substrate } & \multicolumn{2}{|c|}{$\left[{ }^{3} \mathrm{H}\right] \mathrm{dNMP}$ incorporated (pmol) } \\
\hline${ }^{3} \mathrm{H}$-labeled & Unlabeled & Crude extract & Crude extract $+a_{1}$ \\
\hline $\mathrm{dCTP}$ & & 4. 3 & 5.2 \\
\hline dATP & & 0.9 & 1.7 \\
\hline dTTP & & 2.4 & 1.8 \\
\hline dGTP & & 79.7 & 165 \\
\hline dGTP & dATP, dCTP, dTTP & 67.2 & 95.3 \\
\hline
\end{tabular}

DNA polymerase activity was assayed in the reaction mixture containing poly $(\mathrm{dC})$ as described in MAterials AND Methods, but the substrate was altered as shown. The concentration and specific activity of the labeled substrates were the same as those described in the footnote to Table 1.

by polymerase- $a_{1}$ with poly $(\mathrm{dC})$ and poly(dT) because polymerase- $\alpha_{2}$ could not stimulate synthesis with these single-stranded homopolymers. This fact also suggests that the activity in the crude extract with poly $(\mathrm{dC})$ and poly $(\mathrm{dT})$ is that of polymerase$a_{1}$.

When poly $(\mathrm{dC})$ was used as the template, the activity in the crude extract incorporated only dGTP into acid-insoluble material (Table 2). This specific incorporation was stimulated by polymerase- $\alpha_{1}$. Clearly, the DNA synthesis on poly(dC) in the crude extract was not dependent on the terminal deoxynucleotidyl transferase-like activity.

$D N A$ polymerase activity in the crude extract utilizing poly $(d C)$ without added primer is not dependent on an oligonucleotide present in the crude extract nor synthesized by known RNA polymerase. DNA synthesis by purified polymerase- $\alpha_{1}$ with single-

TABLE 3. CHEMICAL NATURE OF THE STIMUlating ACTIVITY OF DNA POLYMERASE $\alpha_{1}$ IN THE CRUDE TUMOR CELL EXTRACT

\begin{tabular}{|c|c|c|c|c|}
\hline \multicolumn{3}{|c|}{ Incubation components } & \multicolumn{2}{|c|}{$\begin{array}{c}{\left[{ }^{3} \mathrm{H}\right] \mathrm{dGMP}} \\
\text { incorporated (pmol) }\end{array}$} \\
\hline Step I & Step II & Step III & $-a_{1}$ & $+a_{1}$ \\
\hline Crude extract & $-\mathrm{a}$ & $+\left[{ }^{3} \mathrm{H}\right] \mathrm{dGTP}$ and $(\mathrm{dC})_{\mathrm{n}}$ & 52.0 & 137 \\
\hline Crude extract + trypsin & + Trypsin inhibitor & $+\left[{ }^{3} \mathrm{H}\right] \mathrm{dGTP}$ and $(\mathrm{dC})_{\mathrm{n}}$ & 0.2 & 11.0 \\
\hline $\begin{array}{l}\text { Crude extract }+ \text { trypsin } \\
\text { and trypsin inhibitor }\end{array}$ & $-\mathrm{a}$ & $+\left[{ }^{3} \mathrm{H}\right] \mathrm{dGTP}$ and $(\mathrm{dC})_{\mathrm{n}}$ & 29.8 & 81.3 \\
\hline
\end{tabular}

To test the chemical nature of the stimulating activity of DNA polymerase $\alpha_{1}$ in crude extract, we set up three sequential incubations. The incubation mixture for Step I $(25 \mu l)$ contained poly $(\mathrm{dC})$ dependent DNA polymerase assay components as described in MATERIALS AND MeTHODs, but with the substrate and template omitted. After mixture for Step I had been incubated for 30 min at $37^{\circ} \mathrm{C}$, the incubation component for Step II $(10 \mu \mathrm{l})$ was added and incubation was continued for an additional $30 \mathrm{~min}$. Then the incubation components for Step III (total volume $10 \mu \mathrm{l}$ ) were added to each tube and incubation was continued for $30 \mathrm{~min}$ at $37^{\circ} \mathrm{C}$ in the presence or absence of DNA polymerase $a_{1}$. Trypsin $(75 \mu \mathrm{g})$ and a trypsin inhibitor $(150 \mu \mathrm{g})$ were added per tube. The amount of protein in the crude extract sample was $26 \mu \mathrm{g}$.

a $10 \mu 1$ of distilled water was added. 
stranded DNA was dependent on a novel RNA polymerase activity by which RNA synthesis was intimately coupled with DNA polymerization (28). There was the possibility that an oligonucleotide was present in the crude extract or was synthesized by known RNA polymerase on the added template and used as a primer for the usual DNA polymerase $a$ activity. Therefore, we checked for the presence of oligonucleotides which could serve as a primer in the crude extract. Enzymes in the crude extract were inactivated by trypsin digestion, then the activity in the crude extract that stimulated the added polymerase- $\alpha_{1}$ on poly $(\mathrm{dC})$ was assayed. If an oligonucleotide is present in the crude extract, polymerase- $\alpha_{1}$ would effectively utilize poly $(\mathrm{dC})$ as a template-primer; but if it does not, polymerase- $\alpha_{1}$ would not utilize poly $(\mathrm{dC})$ because the stimulating factor in the crude extract was inactivated by trypsin digestion. The crude extract incubated first with trypsin lost both its activity for utilizing poly $(\mathrm{dC})$ and its ability to support the activity of added polymerase- $a_{1}$ as shown in Table 3 (lane 2). Thus, participation of a non-protein factor, especially an oligonucleotide, in this activity is unlikely.

Involvement of the known RNA polymerase in the reaction of crude extract then was examined. If RNA is synthesized on the template by RNA polymerase present in the crude extract, poly $(\mathrm{dC})$ which had been incubated with crude extract would act as template-primer, i.e. poly (dC). oligo(rG), for DNA synthesis by added polymerase- $\alpha_{1}$ although the crude extract was digested by trypsin after the incubation. The incubated poly $(\mathrm{dC})$ was not active, as shown in Table 4 (lane 2). If poly(dC) first was incubated with the crude extract and was not digested with trypsin (Table 4, lane 3), it could serve as template, in spite of some loss of activity, which might be ascribable to non-specific inactivation of the stimulating factor and DNA polymerase. This result also rules out the possibility of the degradation of poly $(\mathrm{dC})$ by the nuclease in the crude extract during incubation. RNA polymerases are reported to be highly active with poly(dC) and poly(dT) (23). RNA, which might be synthesized by known RNA polymerases on poly $(\mathrm{dC})$ in the crude extract during the first incubation, showed little activity as a primer for DNA synthesis by polymerase- $\alpha_{1}$ (see Table 4 , lane 2). DNA synthesis by polymerase- $\alpha_{1}$ may start only from the $3^{\prime}-\mathrm{OH}$ terminus of the fold-back strand of poly $(\mathrm{dC})(26)$ or from the RNA primer synthesized by the RNA

TABLE 4. EFFECT OF PRIORINCUBATION OF THE TEMPLATE WITH THE CRUDE EXTRACT ON THE STIMULATING ACTIVITY OF DNA POLYMERASE $a_{1}$

\begin{tabular}{|c|c|c|c|c|}
\hline \multirow[b]{2}{*}{ Step I } & \multicolumn{2}{|c|}{ Incubation components } & \multirow[b]{2}{*}{ Step IV } & \multirow{2}{*}{$\underset{(\text { pmol })}{\left[{ }^{3} \mathrm{H}\right] \mathrm{dGMP}}$} \\
\hline & Step II & Step III & & \\
\hline $\begin{array}{l}(\mathrm{dC})_{\mathrm{n}} \\
+ \text { crude extract }\end{array}$ & - & - & $+\left[{ }^{3} \mathrm{H}\right] \mathrm{dGTP}$ and $\alpha_{1}$ & 64.1 \\
\hline $\begin{array}{l}(\mathrm{dC})_{\mathrm{n}} \\
+ \text { crude extract }\end{array}$ & + Trypsin & $\begin{array}{l}\text { +Trypsin } \\
\text { inhibitor }\end{array}$ & $+\left[{ }^{3} \mathrm{H}\right] \mathrm{dGTP}$ and $\alpha_{1}$ & 6.1 \\
\hline $\begin{array}{l}(\mathrm{dC})_{\mathrm{n}} \\
+ \text { crude extract }\end{array}$ & $\begin{array}{l}\text { + Trypsin and } \\
\text { trypsin inhibitor }\end{array}$ & - & $+\left[{ }^{3} \mathrm{H}\right] \mathrm{dGTP}$ and $\alpha_{1}$ & 32.1 \\
\hline$(\mathrm{dC})_{\mathrm{n}}$ & - & - & $\begin{array}{l}+\left[{ }^{3} \mathrm{H}\right] \mathrm{dGTP}, \alpha_{1} \\
\text { and crude extract }\end{array}$ & 69.1 \\
\hline
\end{tabular}

To test the effect of a priorincubation of the template with the crude extract on the stimulating activity of DNA polymerase $\alpha_{1}$, four sequential incubation were set up. The incubation for each step was carried out for $30 \mathrm{~min}$ at $37^{\circ} \mathrm{C}$. The incubation components used were the same as those described in the footnote to Table 3. 
polymerase activity associated with polymerase- $\alpha_{1}$.

Together with the results in the preceding section, these results show that the activity which utilizes poly $(\mathrm{dC})$ and poly(dT) in the crude exatrct could be identified with polymerase- $\alpha_{1}$. Thus, we used the crude extract to measure polymerase- $\alpha_{1}$ activity.

Subcellular location of polymerase- $\alpha_{1}$. Kaftry and Fry reported that DNA polymerase activity that utilizes single-stranded DNA was present in the chromatin of rat hepatoma cells and was coupled with cell proliferation; this suggests a role in nuclear DNA replication (10). Our results, however, show that the nuclear fraction prepared with hypotonic media containing $\mathrm{MgCl}_{2}$ (21) from Ehrlich ascites cells contained only $20-30 \%$ of the activity in the cells. This distribution resembles that reported for DNA polymerase $a(6)$. Nearly quantitative recovery of the DNA polymerase $\alpha$ in the nuclear fraction can be achieved using the methods of enucleation with cytochalasin B (8) and cell fractionation with a nonaqueous medium (7). Even if there is some ambiguity because of contamination of the perinuclear region of the cytoplasm associated with the karyoplasts (2), the cytochalasin B enucleation procedure is a simple and reliable means for establishing the subcellular location of the enzyme. We therefore examined the subcellular location of polymerase- $\alpha_{1}$ by this technique.

The distribution of polymerase- $\alpha_{1}$ in the subcellular fractions is shown in Table 5 . In the experiment in which Ehrlich ascites cells were centrifuged in Ficoll solution containing cytochalasin B, about $90 \%$ of the cells was enucleated. Crude extracts were prepared from these fractions. The levels of polymerase- $\alpha_{1}$ were assayed with poly $(\mathrm{dT})$ as the template and an addition of excess stimulating factor. The activity in each fraction was corrected according to the degree of enucleation. Our results show that karyoplasts contained $>98 \%$ of the total polymerase- $a_{1}$ activity, whereas about $76 \%$ of the DNA polymerase activity assayed with activated DNA was localized in the karyoplasts. Most of this polymerase activity is ascribed to polymerase- $\alpha_{2}$ (see Fig. 1). Thus, polymerase- $\alpha_{1}$ may be associated with a nucleus tighter than polymerase- $\alpha_{2}$.

Variation of polymerase- $a_{1}$ activity during postnatal development of the spleen and

TABLE 5. INTRACELLULAR DISTRIBUTION OF DNA POLYMERASE $\alpha_{1}$

\begin{tabular}{|c|c|c|c|c|c|c|}
\hline \multirow{2}{*}{ Condition } & \multirow{2}{*}{$\begin{array}{c}\text { Cytoplast } \\
\left(\mu \mathrm{mol}^{\mathrm{d}} / 10^{8} \text { cells }\right)\end{array}$} & \multicolumn{2}{|c|}{$\begin{array}{l}\text { Cytoplast } \\
\text { (corrected) }^{\mathrm{a}}\end{array}$} & \multirow{2}{*}{$\begin{array}{c}\text { Karyoplast } \\
\left(\mu \mathrm{mol}^{\mathrm{d}} / 10^{8} \text { cells }\right)\end{array}$} & \multicolumn{2}{|c|}{$\begin{array}{l}\text { Karyoplast } \\
\text { (corrected) }^{\mathrm{a}}\end{array}$} \\
\hline & & $\mu \mathrm{mol}^{\mathrm{d}}$ & $\%$ & & $\mu \mathrm{mol}^{\mathrm{d}}$ & $\%$ \\
\hline$(\mathrm{dT})_{\mathrm{n}}$ plus $\mathrm{SF}^{\mathrm{b}}$ & 280 & 37 & 1.4 & 2433 & 2676 & 98.6 \\
\hline Activated DNA $^{c}$ & 2661 & 2043 & 23.1 & 6183 & 6801 & 76.9 \\
\hline
\end{tabular}

Subcellular fractionation of Ehrlich ascites cells was done by cytochalasin-B-induced enucleation as described in Materials AND Methods.

a Results are expressed as corrected values according to the efficiency of enucleation. About $10 \%$ of the cytoplasts conteined nuclei.

b The levels of DNA polymerase $\alpha_{1}$ were assayed with poly(dT) as the template and excess stimulating factor(SF) added, as described in Materials AND Methods.

c The activity of total DNA polymerase $\alpha$ was assayed with activated DNA as the template-primer as described previously (12).

d The values indicate the dAMP or dTMP incorporoted into acid-insoluble materials. 


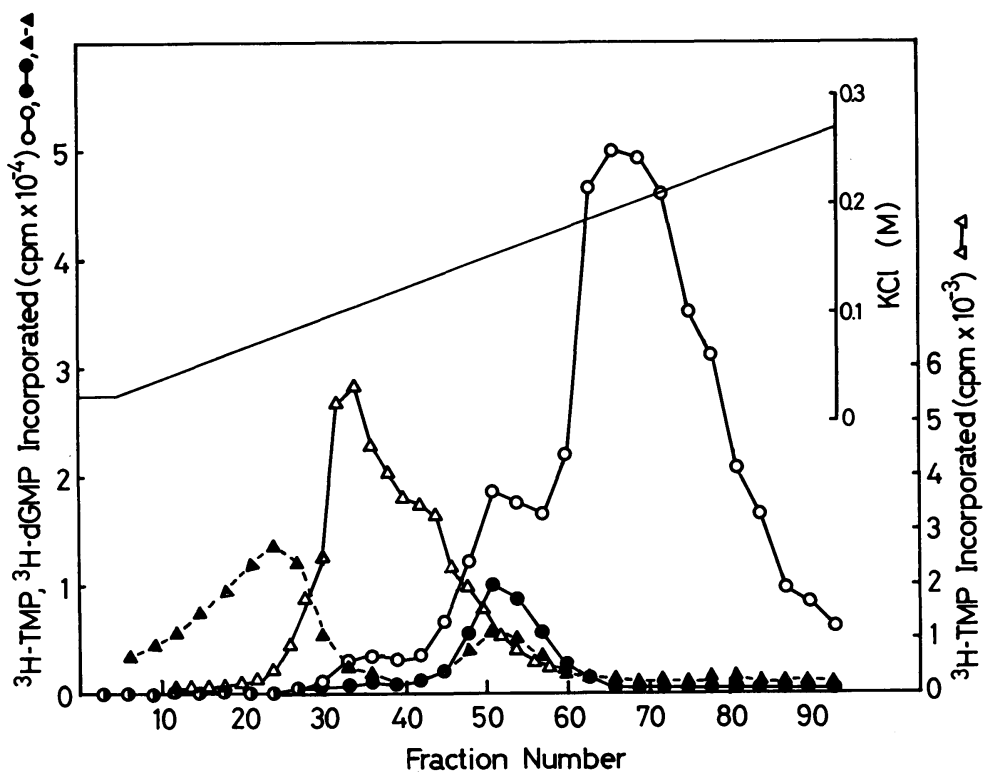

Fig. 1. DEAE-cellulose column chromatography of DNA polymerase $a_{1}$. The active fractions of backwashes of ammonium sulfate precipitate prepared from crude extracts of Ehrlich ascites cells $(200 \mathrm{~g})$ were applied to a DEAE-cellulose column $(2 \times 45 \mathrm{~cm})$ which had been equilibrated with $50 \mathrm{mM}$ Tris- $\mathrm{HCl}$ (pH 7.6), $0.1 \mathrm{mM}$ EDTA, $1 \mathrm{mM}$ dithiothreitol, $20 \%$ glycerin, $10 \mathrm{mM} \mathrm{KCl}$. The column was washed with 3 column bed volumes of the above buffer. Enzymes were eluted with a linear gradient of $10 \mathrm{mM}$ to $400 \mathrm{mM} \mathrm{KCl}$ in this buffer. DNA polymerase activity assayed with poly $(\mathrm{dC})(\bullet)$, activated DNA $(\bigcirc)$, or poly $(\mathrm{rA}) \cdot$ oligo(dT) $(\triangle)$. The stimulating factor was assayed as the stimulation of polymerase- $\alpha_{1}$ activity with poly $(\mathrm{dC})(\boldsymbol{A})$.

cardiac muscle. To examine the relationship between the levels of polymerase- $a_{1}$ activity and cellular proliferation, we selected the postnatal development systems of the spleen and cardiac muscle which have been well studied. The spleen is an organ characterized by a burst of postnatal cell proliferation (22); in cardiac muscle, DNA synthesis is active in the foetus and after birth the rate of DNA synthesis rapidly decreases (9).

The incorporation of $\left[{ }^{3} \mathrm{H}\right]$ thymidine into the DNA of the spleen increased after birth, reaching a maximum on the 5th day of the postnatal stage and decreasing gradually to almost zero by adulthood (Fig. 2A, inset). The levels of polymerase- $\alpha_{1}$ activity increased after birth, reaching a maximum on the 5th day then decreasing (Fig. 2A), paralleling the change in the rate of $\left[{ }^{3} \mathrm{H}\right]$ thymidine incorporation. The levels of DNA polymerase activity assayed with activated DNA showed a pattern similar to that of polymerase- $a_{1}$. But, the incorporation of $\left[{ }^{3} \mathrm{H}\right]$ thymidine into the DNA of cardiac muscle decreased following birth and stopped from the 15th-20th day of postnatal development (Fig. 2B, inset). The levels of polymerase- $\alpha_{1}$ activity paralleled the decrease in $\left[{ }^{3} \mathrm{H}\right]$ thymidine incorporation (Fig. 2B). The levels of DNA polymerase activity assayed with activated DNA decreased in the same manner. Both DNA polymerase activities in cardiac muscle were low compared with those in the spleen, indicative of the low DNA synthetic activity of cardiac muscle (note that the $\left[{ }^{3} \mathrm{H}\right]-$ thymidine incorporated by cardiac muscle was less than that by spleen by about one order of magnitude). We therefore concluded that the levels of polymerase- $\alpha_{1}$ positive- 


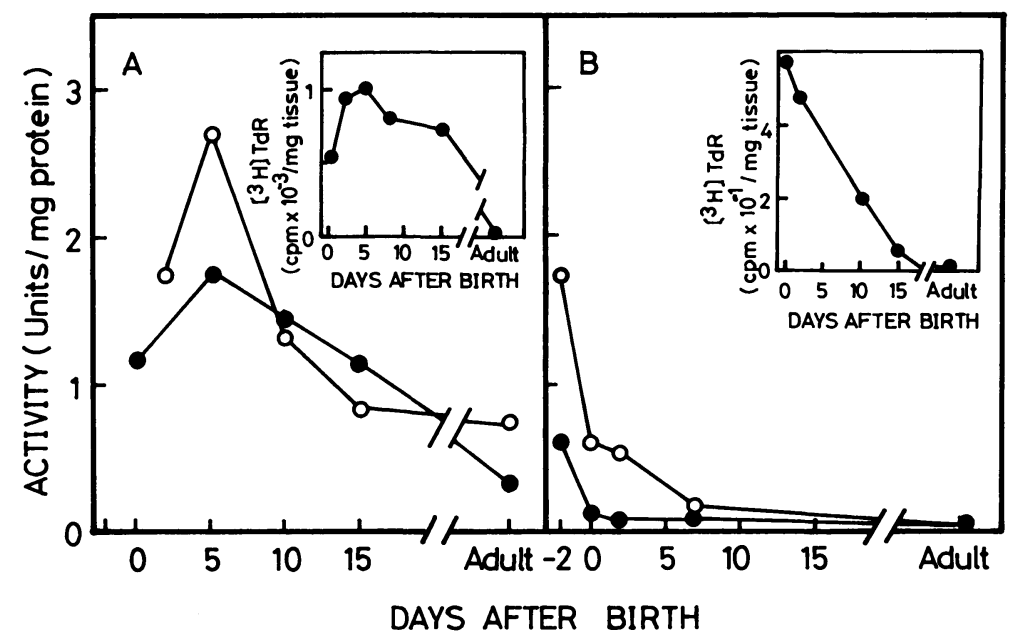

Fig. 2. Variation of DNA polymerase $a_{1}$ activity during postnatal development of the spleen (A) and cardiac muscle (B). DNA polymerase $\alpha_{1}$ activity in the crude extracts was determined with poly $(\mathrm{dC})$ as the template $(\bullet)$. DNA polymerase $\alpha$ activity was assayed with activated DNA $(O)$ as described in MATERIALS AND METHODS. DNA polymerase activities are given as units per mg protein. The insets in the figures show $\left[{ }^{3} \mathrm{H}\right]$ thymidine incorporation into DNA per milligram of tissue measured as described in MAterials AND Methods.

ly are correlated with the rate of cellular DNA synthesis in the spleen and in cardiac muscle.

These results also show that polymerase- $\alpha_{1}$ activity is present both in tumor cells and in normal tissue, in which cells actively proliferate. Combined with the fact that polymerase- $\alpha_{1}$ was tightly associated with the nucleus, these observations are strong support for polymerase- $a_{1}$ having a role in DNA replication. In this it is important that polymerase- $\alpha_{1}$ has a novel RNA polymerase activity which is resistant to a high concentration of $a$-amanitin and is thought to synthesize primer RNA for subsequent DNA polymerization (28). Since this novel RNA polymerase activity was copurified with polymerase- $\alpha_{1}$ (by ion exchange column chromatographies and glycerol gradient centrifugation), polymerase- $\alpha_{1}$ must be associated with this activity, and should participate in the initiation and elongation of Okazaki fragments in cell nuclei.

Acknowledgments. We thank Mrs. M. Saitoh of this Institute for her assistance in preparing the newborn mice. This research was supported in part by a Grant-in-Aid for Cancer Research from the Ministry of Education, Science and Culture of Japan.

\section{REFERENCES}

1. Bertazzoni, V., M. Stefanini, G.P. Noy, E. Giulotto, F. Nuzzo, A. Falashi and S. Spadari. Variation of DNA polymerase- $\alpha$ and $-\beta$ during prolonged stimulation of human lymphocytes. Proc. Natl. Acad. Sci. U.S.A. 73, 785-789, 1976

2. Brown, M., F.J. Bollum and L.M.S. ChANG. Intracellular localization of DNA polymerase $a$. Proc. Natl. Acad. Sci. U.S.A. 78, 3049-3052, 1981

3. Burton, K. A study of the conditions and mechanism of the diphenylamine reaction for the 
colorimetric estimation of deoxyribonucleic acid. Biochemical J. 62, 315-323, 1956

4. Claycomb, W.C. Biochemical aspects of cardiac muscle differentiation. J. Biol. Chem. 250, 3229-3235, 1975

5. Edenberg, H.J., S. Anderson and M.L. DePamphilis. Involvement of DNA polymerase $a$ in simian virus 40 DNA replication. $J$. Biol. Chem. 253, 3273-3280, 1978

6. EICHLER, D.C., P.A. Fisher and D. KORN. Effect of calcium on the recovery and distribution of DNA polymerase a from human cells. J. Biol. Chem. 252, 4011-4014, 1977

7. FOSTER, D.N. and T. GURNEY. Nuclear location of mammalian DNA polymerase activities. J. Biol. Chem. 251, 7893-7898, 1976

8. Herrick, G., B.B. SpeAr and G. VeOMetT. Intracellular localization of mouse DNA polymerasea. Proc. Natl. Acad. Sci. U.S.A. 73, 1136-1139, 1976

9. Hubscher, U., C.C. Kuenzle and S. Spadari. Variation of DNA polymerase- $\alpha,-\beta$, and $-\gamma$ during perinatal tissue growth and differentiation. Nucleic Acid Res. 4, 2917-2929, 1977

10. Kaftry, A. and M. Fry. Highly efficient copying of single-stranded DNA by eukaryotic cell chromatin. Nucleic Acids Res. 5, 2679-2693, 1978

11. KozU, T., M. Aida, Y. Ikawa and T. Seno. Analysis of synthetic RNA-directed DNA polymerase activities in the spleen of a rat with myelogenous leukemia induced by N-nitro-N-butylurea. Europ. J. Cancer 14, 1065-1076, 1978

12. Kozu., T. Kurihara and T. Seno. Heterogeneous forms of poly(rA).oligo(dT) directed DNA polymerase activity from rat spleen. J. Biochem. 89, 551-561, 1981

13. KrokAn, H., P. Schaffer and M.L. DePAMPhilis. Involvement of eukaryotic deoxyribonucleic acid polymerase $\alpha$ and $\gamma$ in the replication of cellular and viral deoxyribonucleic acid. Biochemistry 18, 4431-4443, 1979

14. LONGaCre, S. and W.J. RutTer. Nucleotide polymerases in the developing avian erythrocyte. J. Biol. Chem. 252, 273-283, 1977

15. Lowry, O.H., N.J. Rosebrough, A.L. Farr and R.J. Randall. Protein measurement with the folin phenol reagent. J. Biol. Chem. 193, 265-275, 1951

16. Mechali, M., J. Abadiedebat and A.M. De Recondo. Eukaryotic DNA polymerase a. $J$. Biol. Chem. 255, 2114-2122, 1980

17. MorRIS, P.W. and M. RACINE. Ribonucleotidyl transferase in preparations of partially purified DNA polymerase $\alpha$ of the sea urchin. Nucleic Acids Res. 5, 3959-3973, 1978

18. Novak, B. and E.F. BARIL. HeLa DNA polymerase a activity in vitro: Specific stimulation by a non-enzymic protein factor. Nucleic Acids Res. 5, 221-239, 1978

19. Otto, B., M. BAyNes and R. KNIPPERS. A single-stranded-specific DNA-binding protein from mouse cells that stimulates DNA polymerase. Its modification by phosphorylation. Eur. $J$. Biochem. 73, 17-24, 1977

20. De Recondo, A.M., J.A. Lepesant, O. Fichot, L. Grasset, J.M. Rossignol and M. Cazillis. Synthetic template specificity of a deoxyribonucleic acid polymerase from regenerating rat liver. J. Biol. Chem. 248, 131-137, 1973

21. Sakuma, K., R. Kominami and M. Muramatsu. Conservation of the 5'-terminal nucleotide sequences of ribosomal 18-S RNA in eukaryotes. Eur. J. Biochem. 63, 339-350, 1976

22. Spear, P.G., A. Wang, U. Rutishauser and G.M. Edelman. Characterization of splenic lymphoid cells in fetal and newborn mice. J. Exp. Med. 138, 557-573, 1973

23. TAKIYA, S., Y. TAKoH and M. IwabUCHI. Template specificity of DNA-dependent RNA polymerases I and II for synthetic polynucleotides during development of the cellular slime mold Dictyosterium discoideum. J. Biochem. 87, 1501-1509, 1980

24. WANG, E.C., D. Henner and J.J. Furth. Duplication of single stranded DNA catalyzed by calf thymus DNA polymerase $a$. Nucleic Acids Res. 3, 129-147, 1976

25. Wigler, M.H. and B. Weinstein. A preparative method for obtaining enucleated mammalian cells. Biochem. Biophys. Res. Commun. 63, 669-674, 1975

26. Yagura, T., T. Kozu and T. Seno. Partial purification and characterization of poly(dC)-dependent DNA polymerase and its stimulating factor. Biochem. Biophys. Res. Commun. 92, 1289-1296, 1980 
27. Yagura, T. and T. Seno. DNA synthesis in isolated chromatin. Nature of activities, and relationship to kinetics of DNA polymerase release from chromatin DNA. Biochim. Biophys. Acta 608, 277-286, 1980

28. Yagura, T., T. Kozu and T. Seno. Mouse DNA polymerase accompanied by a novel RNA polymerase activity: Purification and partial characterization. J. Biochem. 91, 607-618, 1982

(Received for publication, October 19, 1981) 